ОСОБЛИВОСТІ ФОРМУВАННЯ ЕЛЕМЕНТІВ СТРУКТУРИ ПРОДУКТИВНОСТІ КУКУРУДЗИ ЗАЛЕЖНО ВІД НАЯВНОСТІ В ЇХ МАТЕРИНСЬКОМУ КОМПОНЕНТІ ГЕНЕТИЧНИХ МАРКЕРІВ

\author{
М. О. МАКАРЧУК, здобувач * \\ Уманський національний університет садівництва
}

E-mail: marishka2708@ukr.net

Анотація. Наведено особливості формування основних елементів продуктивності у коізогенних аналогів гібридів кукурудзи за наявності у їх материнських компонентах генетичних маркерів a2 $i$ ACR y різних генетичних системах контрольованого розмноження. Доведено, щчо в умовах Правобережного Лісостепу $i$ Південного Cтепу наявність у генотипі гібридів домінантних генетичних маркерів ACR не знижує продуктивність, а навіть сприяе ї̈ підвищенню.

Ключові слова: гібрид, коізогенний аналог, генетичний маркер, молдавський і парагвайський типи стерильності, закріплювач фертильності

Реалізація генетичного потенціалу нових гібридів забезпечується завдяки впровадженню інноваційних технологій вирощування, невід’ємною складовою яких $є$ отримання високоякісного насіння. Для спрощення контролю за гібридністю насіння, а відтак і здешевлення його виробництва використовуємо генетичні маркери забарвлення зернівки. Актуальним завданням є з'ясування впливу генетичних маркерів у різних ГСКР на господарсько-цінні ознаки гетерозисних гібридів кукурудзи порівняно 3 традиційними способами виробництва гетерозисного насіння у різних агроекологічних умовах.

Кукурудза є однією з найбільш головних зернових і кормових культур. Біологічні особливості іiі росту і розвитку сприяють вирощуванню як в Україні, так і далеко за їі межами. Довгий період в основному вирощувалися

\footnotetext{
*Науковий керівник - кандидат сільськогосподарських наук, професор А. І. Опалко
} 
сорти-популяції, але завдяки підвищеному адаптивному потенціалу і вищій врожайності гетерозисні гібриди витіснили їх з виробництва ще в середині минулого сторіччя $[1,2]$.

Внаслідок дефіциту якісного вітчизняного насіння збільшився відсоток імпортного посівного матеріалу, який за адаптивною здатністю гірше пристосований до наших умов вирощування [3]. Тому, вдосконалення методів отримання гібридного насіння кукурудзи для певних грунтовокліматичних умов дасть можливість одночасно зменшити його собівартість, а також збільшити виробництво зерна за рахунок повного розкриття генетичного потенціалу [4].

Найбільш поширеним способом здешевлення виробництва насіння гетерозисних гібридів сільськогосподарських культур, зокрема кукурудзи, $\epsilon$ використання материнських ліній 3 різними формами цитоплазматичної стерильності як найбільш вживаними варіантами генетичної системи контрольованого розмноження (ГСКР) кукурудзи. Загальновідомо, що найбільш поширеним способом зниження видатків під час виробництва гетерозисного гібридного насіння кукурудзи $є$ використання механізмів цитоплазматичної чоловічої стерильності (ЦЧС) як одного 3 найбільш вивчених варіантів генетичної системи контрольованого розмноження (ГСКР) [5]. У гібридному насінництві кукурудзи в Україні нині переважають молдавський (M) і парагвайський (C) типи стерильності.

Однак проблеми уніфікації плазми спонукають до пошуку нових ГСКР насамперед на основі генів функціональної чоловічої стерильності $V g$ (Vestigial glume), без порушень генетичних механізмів мікроспоро- та мікрогаметогенезу [6]. Спрощення контролювання гібридності насіння, а відтак здешевлення його виробництва, досягається завдяки запропонованим Ф. М. Парієм із співавторами [7] маркерним генам забарвлення зернівки кукурудзи, які тісно зчеплені зі згаданим геном функціональної чоловічої стерильності [8], а також на базі зчеплених генів ядерної чоловічої 
стерильності (Ms5/ms5 i Ms13/ms13) 3 маркерними генами (A2/a2) забарвлення зернівки кукурудзи [9].

Мета дослідження - вивчити ефективні методи генетичного контролювання чистоти гібридного насіння кукурудзи із використанням генетичних маркерів у різних генетичних системах контрольованого розмноження (ГСКР) для створення високоякісного гібридного насіння зі збереженням урожайних і посівних якостей та високої типовості гібридного насіння для умов Правобережного Лісостепу і Південного Степу.

Методи i матеріали дослідження. Випробовування гібридів проводили за методикою державного сортовипробування [10] та інтенсивної технології вирощування зернових культур [11] у двох пунктах з різними грунтово-кліматичними умовами - в Уманському національному університеті садівництва (УНУС), розташованому в зоні Правобережного Лісостепу, і на Брилівській дослідній станції (БДС) - у Південному Степу України. Статистичний аналіз проводили за Р. Фішером (Fisher, 2006) 3 перевіркою гіпотез на рівні значущості не менше 0,05 [12]. Розрахунки виконували за спеціальними програмами для персонального комп’ютера "STAT" та MS "Exel".

У досліді вивчали коізогенні аналоги простого гібрида Піонер-Гран 3978 отриманого під час схрещування стерильного материнського компонента П3Са2a2 з генетичним маркером a2 (Antocianinless), який в гомозиготному стані визначає відсутність антоціанового забарвлення в алейроні і батьківського компонента П5СВСІСІ 3 генами відновлення фертильності та маркером CI (Dominant colorles), який пригнічує прояв пурпурового або червоного забарвлення: П3зС $а 2 a 2 \times П 5 \mathrm{CBCICI} \mathrm{(материнська}$ форма в гібридній комбінації фертильний закріплювач молдавського типу стерильності 3 тим же генетичним маркером); П3зМАCR $\times$ П5МВСВ $-R R$ (материнський компонент - фертильний закріплювач стерильності молдавського типу з генетичними маркерами $A C R$, які в гомозиготному стані визначають наявність антоціанового забарвлення алейрону i перикарпію, 
батьківська лінія - 3 генами відновлення фертильності має маркер $P-R R$, який викликає червоне забарвлення перикарпію). Також вивчали аналоги трилінійного гібрида Гран-6, у насінництві якого використовується материнський компонент парагвайського типу стерильності і батьківський - 3 генами відновлення фертильності i генетичним маркером a1): П73С $\times$ П26CBalal (гібридна комбінація з материнською лінією - фертильний закріплювач парагвайського типу стерильності); П7зСACR $\times 26 \mathrm{CBCICI}$ (гібридна форма 3 тією ж материнською лінією i маркерами $A C R$, a батьківська лінія - з генами відновлення фертильності має маркер $C I$ ).

Результати досліджень та їх обговорення. Урожайність $є$ одним із найважливіших критеріїв оцінки вирощуваних гібридів. Результати досліджень показали, що величина урожаю залежала від умов вирощування більше, ніж від генотипу. Під час вирощування коізогенних аналогів простого гібрида Піонер-Гран 3978 і трилінійного - Гран-6 у умовах Правобережного Лісостепу всі гібридні комбінації забезпечили істотне збільшення врожаю відповідно на 0,50 і 1,98 та 0,35 і 1,89 т/га (рис. 1.).

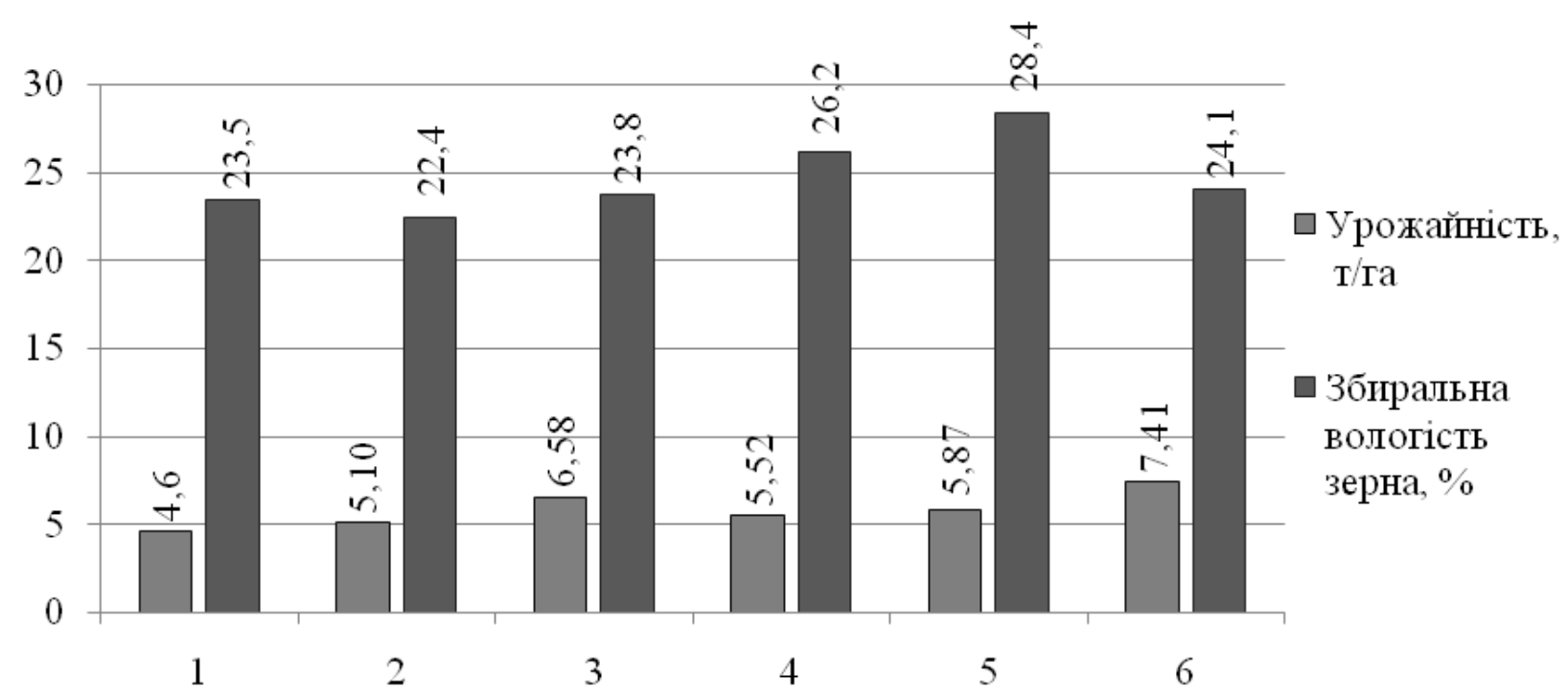

Рис. 1. Врожайність, вологість зерна під час збирання коізогенних аналогів в умовах Правобережного Лісостепу: 1 - П3Са2а2×П5СВCICI (контроль - Піонер-Гран 3978 ); 2 - П3зСа2а2 П5СВСICI; 3 П3зМACR $\times \Pi 5 M B C В P-R R ; 4-\Pi 7 C \times \Pi 26 C B a 1 a 1$ (контроль); 5 $\Pi 73 \mathrm{C} \times \Pi 26 \mathrm{CBa1a1} ; 6-\Pi 73 \mathrm{CACR} \times \Pi 26 \mathrm{CBCICI}$ 
Найвищу зернову продуктивність забезпечили коізогенні аналоги за наявності у їх материнських компонентах домінантних генетичних маркерів ACR відповідно 6,58 т/га і 7,41 т/га.

Одним із важливих показників урожайності є вологість зерна під час збираня. Зменшення вологості зерна в умовах Лісостепу спостерігали у коізогенних аналогів простого гібрида Піонер-Гран 3978 П3зС $а 2 a 2 \times \Pi 5$ СВCICI з генетичним маркером $a 2$ на $1,1 \%$, та трилінійного гібрида П7зСACR $\times П 26 \mathrm{CBCICI}$ на 2,1 \% вологості. Та за даними збиральної вологості зерна серед аналогів найменший відсоток забезпечила гібридна комбінація П7зСACR $\times$ П26ССCCI при наявності у генотипі домінантних генетичних маркерів ACR.

Розглядаючи детально дані врожайності аналогів в умовах Південного Степу можна вказати що прибавку врожаю 1,04 т/га забезпечила гібридна комбінація П3зМАCR $\times П 5 \mathrm{MBCВP-RR,} \mathrm{тоді} \mathrm{як} \mathrm{аналоги} \mathrm{трилінійного} \mathrm{гібрида}$ $\Pi 73 \mathrm{C} \times \Pi 26 \mathrm{CB}$ alal і П73С $А C R \times П 26 \mathrm{CBCICI}$ мали відповідно 0,56 і 1,13 т/га (рис. 2.).

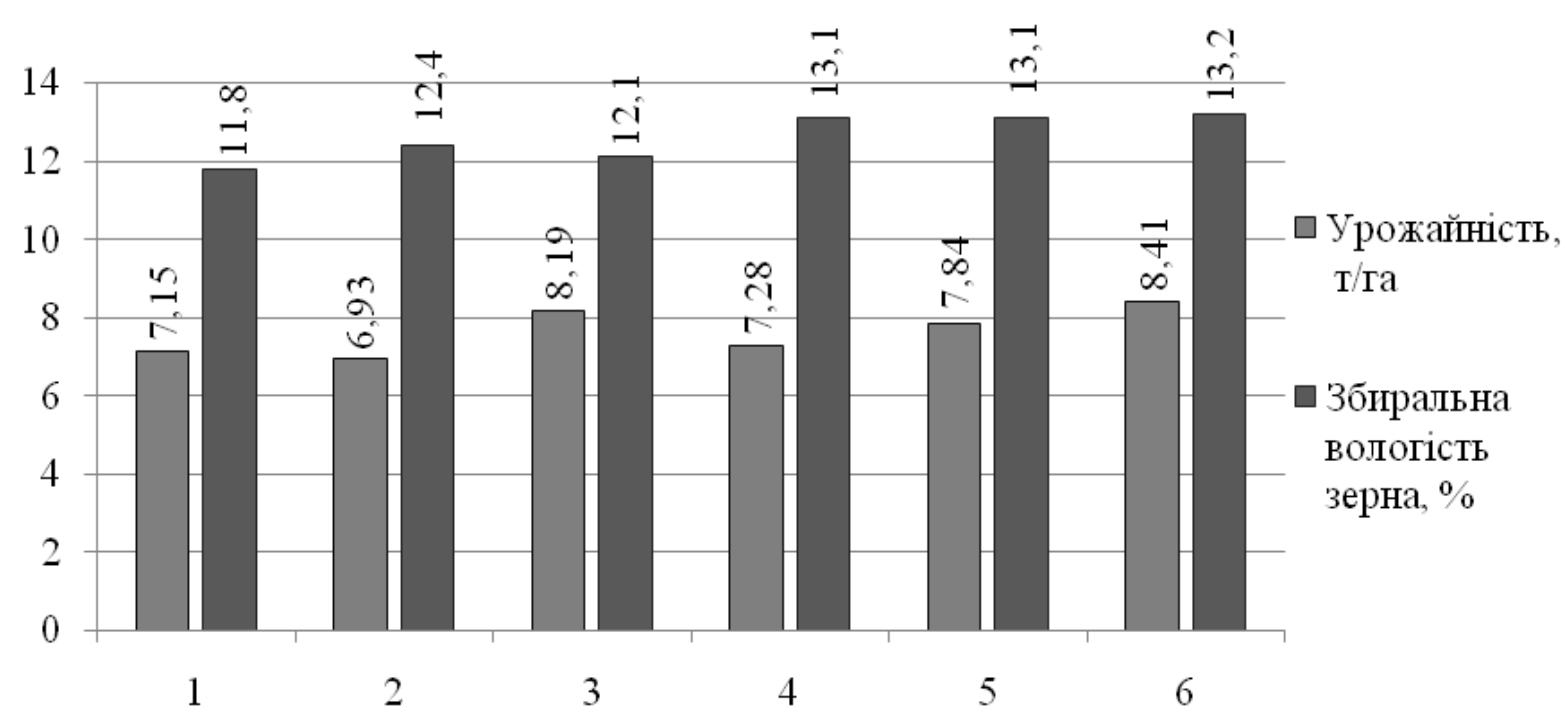

Рис. 2. Урожайність, вологість зерна під час збирання у коізогенних аналогів в умовах Південного Степу: 1 - П3Са2a2×П5СВCICI (контроль); 2 - П3зСа2a2×П5СВCICI; 3 - П3зМACR $\times$ П5МВCВP-RR; 4 П7С $\times$ П26СВа1а1 (контроль); 5 - П73С $\times \Pi 26 \mathrm{CBa1a1;} 6$ П73CACR $\times$ П26CBCICI 
Найвищу зернову продуктивність у досліді мали аналоги за наявності у генотипі материнських компонентів генетичних маркерів $A C R$ у простого гібрида 8,19 та трилінійного - 8,41 т/га.

Слід відмітити, що збиральна вологість зерна у коізогенних аналогів дещо збільшилась у порівнянні із контрольними варіантами, але вона не перевищувала базисної вологості (14\%), а отже таке зерно не потребувало досушування.

Основними складовими елементами продуктивності кукурудзи, які впливають на формування урожайності є морфометричні ознаки: довжина i діаметр качана, кількість рядів зерен і кількість зерен у ряду. У наших дослідженнях в умовах Правобережного Лісостепу довжина качана збільшилась у аналогів простого гібрида П3зМ $A C R \times \Pi 5 \mathrm{MBCB} P-R R$ на 2,4 см, тоді як трилінійного П7зСACR $\times 26 \mathrm{CBCICI} \mathrm{-} \mathrm{на} \mathrm{0,6} \mathrm{см.} \mathrm{(рис.} \mathrm{3).} \mathrm{Діаметр}$ качана також збільшився у аналогів обох гібридів.

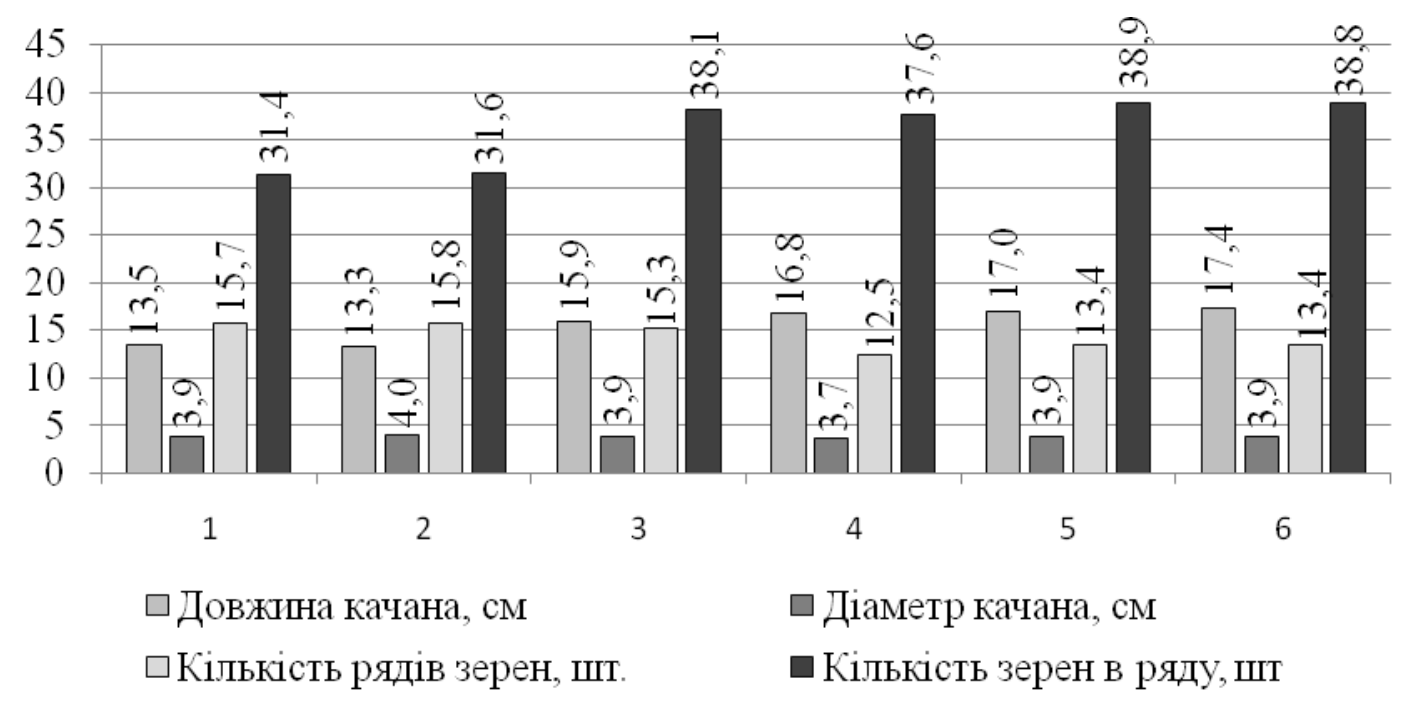

Рис. 3. Елементи структури продуктивності коізогенних аналогів в умовах Правобережного Лісостепу: 1 - П33Са2a2×П5СВCICI (контроль);

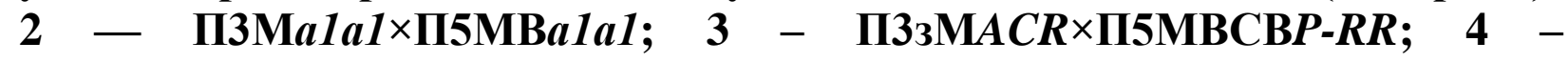
П7С $\times$ П26СВа1a1 (контроль); 5 - П73С $\times$ П26СВа1a1; 6 $\Pi 73 \mathrm{CACR} \times \Pi 26 \mathrm{CBCICI}$

За кількістю рядів зерен у коізогенних аналогів спостерігалась тенденція до збільшення показника. Найбільше його значення забезпечили аналоги трилінійного гібрида П73С $\times П 26 \mathrm{CB}$ alal і П73С $\mathrm{CR} \times \Pi 26 \mathrm{CBCICI}$. За 
кількістю зерен у качані, як і 3 попереднім показником, аналоги мали збільшення ознаки. Найбільшу різницю (6,7 шт.) мала гібридна комбінація $\Pi 33 \mathrm{MACR} \times \Pi 5 \mathrm{MBCB} P-R R$ за наявності у генотипі материнського компоненту домінантних генетичних маркерів $A C R$.

За даними, отриманими в умовах Південного Степу, довжина качана збільшилась на 0,2-1,6 см у аналогів простого гібрида, тоді як у аналогів трилінійного спостерігали зменшення показника на 1,1-1,6 см (рис. 4). Діаметр качана також збільшився, але найбільше значення мали аналоги простого гібрида $\Pi 33 \mathrm{MACR} \times \Pi 5 \mathrm{MBCB} P-R R-4,4 \mathrm{~cm} \quad$ та трилінійного $\Pi 73 \mathrm{CACR} \times \Pi 26 \mathrm{CBCICI}-4,1 \mathrm{~cm}$.

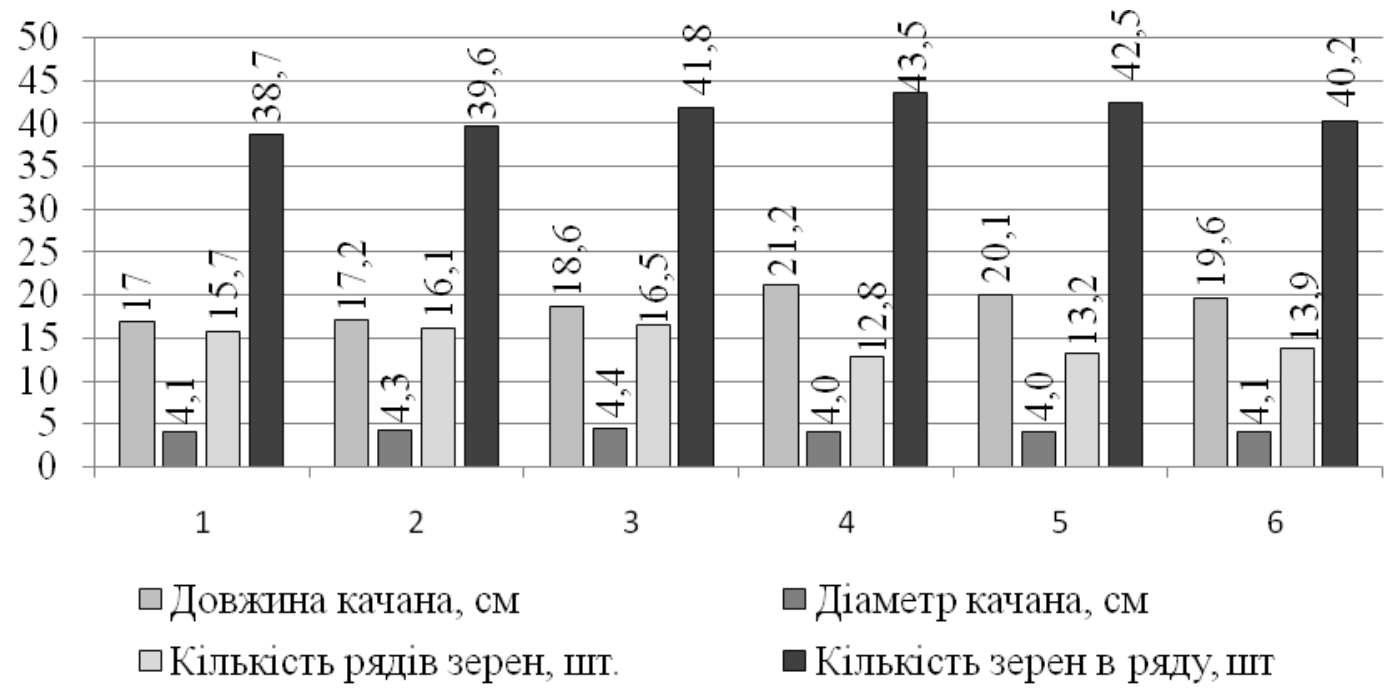

Рис. 4. Елементи структури продуктивності коізогенних аналогів в умовах Південного Степу: 1 - П3Са2a2×П5СВCICI (контроль); 2 -

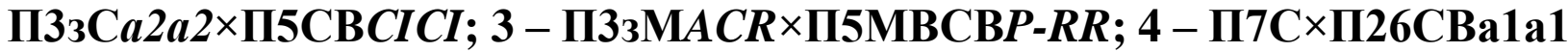
(контроль);5 - П73С ×П26СВa1a1; 6 - П73CACR $\times$ П26CВCICI

Кількість рядів зерен у качані збільшилась на 0,8-1,1 шт. відповідно у аналогів П3зМ $C R \times \Pi 5 \mathrm{MBCBP-RR}$ i П73CACR $\times \Pi 26 \mathrm{CBCICI.} \mathrm{За} \mathrm{кількістю}$ зерен в ряду зростання показника мали аналоги простого гібрида відповідно на 0,9 і 3,1 шт. за наявності у генотипі аналогів материнських компонентів генетичних маркерів $a 2$ і $A C R$. Проте на цей показник зворотній вплив мали генетичні маркери у аналогів трилінійного гібрида, оскільки кількість рядів зерен у аналогів зменшилась відповідно на 1,0 i 3,3 шт, у гібридних комбінаціях П73С×П26CBalal i П73CACR $\times П 26 \mathrm{CBCICI.}$ 
Висновки і перспективи подальших досліджень. Аналіз наших досліджень показав, що досліджувані коізогенні аналоги порівняно 3 базовими контрольними гібридами мали вищу продуктивність. Разом 3 тим максимальна врожайність у обох зонах випробовування була у гібридної комбінації П7зСАCR П26CВCICI, а також в умовах Південного Степу у аналога простого гібрида П3зMACR×П5MBCBP-RR.

Стабільне збільшення показників довжина качана і кількості зерен у ряду в умовах Правобережного Лісостепу і Південного Степу мав аналог П3зМАCR $\times П 5 \mathrm{MBCВP-RR} 3$ материнською лінією фертильний закріплювач стерильності молдавського типу 3 генетичними маркерами ACR, які в гомозиготному стані визначають наявність антоціанового забарвлення алейрону i перикарпію, та батьківська лінія - 3 генами відновлення фертильності має маркер $P-R R$, який викликає червоне забарвлення перикарпію.

Отже, отримані в наших дослідах результати свідчать про можливість впровадження в насінництво гібридної кукурудзи генетичних маркерів забарвлення зернівки, зчеплені 3 генами чоловічої стерильності для спрощення контролювання гібридності насіння без негативного впливу на врожайні якості насіння.

\section{Список використаних джерел}

1. Чучмій I. П. Досягнення і перспективи селекції гібридів кукурудзи для умов Лісостепу і Полісся України / I. П. Чучмій, I. В. Ковальчук, В. С. Борейко // Науковий вісник Національного аграрного університету. 2002. - Вип. 48. - С. 20-25.

2. Макарчук М. О. Використання генів чоловічої стерильності для виробництва гетерозисного гібридного насіння кукурудзи // Матеріали II міжнародної наукової конференції студентів та аспірантів: Молодь та поступ біології, Львів, 21-24 березня 2006 р. - Львів: ЛНУ імені Івана Франка, 2006. - С. 144-145.

3. Рибка В. С. Які гібриди кукурудзи вигідніше вирощувати в умовах зони Степу України /[В. С. Рибка, Н. О. Ляшенко, В. Ю. Черчель, О. Ю. Шишкіна]// Агроном. - 2007. - № 4 (18). - С. 50-54.

4. Заїка С. П. Селекція скоростиглих гібридів кукурудзи на високу зернову продуктивність та адаптивність / С. П. Заїка, Л. І. Перевертун // 
Науковий вісник Національного аграрного університету. - 2002. - Вип. 48. C. 30-34.

5. Опалко А. И. Генетические системы контролируемого размножения кукурузы / А. И. Опалко, М. А. Макарчук // Методы и технологии в селекции растений и растениеводстве: матер Международ. научно-практ. конф. «Методы и технологии в селекции растений и растениеводстве», НИИСХ Северо-Востока, г. Киров, 2-3 апреля 2015 г. / Редкол.: В. А. Сысуев (глав. ред.) и др., - Киров: НИИСХ Северо-Востока, 2015. - С. 397-402.

6. Опалко А. І. Проблеми і перспективи використання гетерозисного ефекту у селекції рослин / А. І. Опалко, М. А. Макарчук, О. В. Поліщук // Генетика i селекція: досягнення та проблеми: тези i доп. Міжнародної наукової конференції, присв. 110-річчю від дня народ. ... Ю. П. Мірюти, УНУС, м Умань, 18-20 березня 2015 р. / Редкол.: О. О. Непочатенко (відп. ред.) та ін. - Умань: УНУС, 2015. - С. 86-89.

7. Парій Ф. М. Використання генетичних маркерів у виробництві гетерозисного гібридного насіння кукурудзи / Ф. М. Парій, О. П. Опалко, М.О. Макарчук // Зб. наук. праць Уманського ДАУ. - 2008. - Вип. 67. - с. 6368.

8. Парій Я. Ф. Створення аналога лінії $\mathrm{F} 23 \mathrm{C}$ з введенням алелів генів забарвлення алейронового шару зернівки // Науковий вісник Національного аграрного університету. - 2002. - Вип. 48. - С. 159-166.

9. Парій М. Ф. Контроль алелів генів стерильності у кукурудзи при розмноженні стерильних форм на основі двох генів чоловічої стерильності та маркерного гена / М. Ф. Парій, Я. Ф. Парій, Ф. М. Парій // Зб. наук. праць Уманського НУС. - 2013. - Вип. 83. - с. 56-62.

10. Методика державного випробування сільськогосподарських культур / Під. ред. В. В Волкодава. - К. - 2001. - Вип. 2. - 65 с.

11. Інтенсивні технології вирощування зернових культур в Херсонській області: методичні рекомендації / В. А. Писаренко, Б. І. Лактіонов, І. Т. Нетіс [та ін.] - Херсон, 1992. - 30 с.

12.Fisher R. A. Statistical methods for research workers / Ronald A. Fisher/ — New Delhi: Cosmo Publications. - 354 p.

\section{References}

1. Chuchmiy I. P, Kovalchuk I. V., Boreyko V. S. (2002). Achievements and prospects of maize hybrids selection for the conditions of Forest-Steppe and Forest Area of Ukraine. Scientific Bulletin of National Agrarian University, 48, 20-25.

2. Makarchuk M. O. (2006). The use of male sterility genes for the production of heterotic hybrid seeds of maize // Materials of the II International scientific conference for students and postgraduate students: Youth and progress of biology, Lviv, 21-24 March 2006, Lviv: Ivan Franko LN, 144-145.

3. Rybka V. S., Lyashenko N. O., Cherchel V. Yu., Shyshkina O. Yu. (2007). What maize hybrids are more profitable to grow in the zone of the Steppe of Ukraine. Agronomist, 4 (18), 50-54. 
4. Zaika S. P., Perevertun L. I. (2002). Breeding of early maturing maize hybrids for high grain yield and adaptability. Scientific Bulletin of National Agrarian University, 48, 30-34.

5. Opalko A. I., Makarchuk M. O. (2015). Genetic systems of the maize controlled reproduction. Techniques and technologies in plant breeding and crop production: Materials of International scientific-practical. conf. "Methods and technologies of plant breeding and crop production", Research Institute of Agriculture of North-East, 397-402.

6. Opalko A. I., Makarchuk M. O., Polishchuk O. V. (2015). Problems and prospects of using heterosis effect in plant breeding. Genetics and breeding: progress and problems: Materials of International scientific conference / assigned to 110-th anniversary of the birthday of Yu. P. Miruta, 86-89.

7. Pariy F. M., Opalko O. P., Makarchuk M. O. (2008). The use of genetic markers in the maize heterotic hybrid seed production. Collection of research papers of Uman SAU, 67, 63-68.

8. Pariy Ya.F.(2002). The establishment of the analogue of $\mathrm{F} 23 \mathrm{C}$ line with the introduction of the alleles gene of the aleurone layer of the caryopsis coloring. Scientific Bulletin of National Agrarian University, 48, 159-166.

9. Pariy M. F., Pariy Ya. F., Pariy F. M. (2013). Control alleles of maize sterility genes while breeding sterile forms on the basis of two genes of male sterility and marker gene. Collection of research papers of Uman NUH, 83, 56-62.

10. Volkodav. V. V. (2001). The method of state trials of crops, 2, 65.

11. Pysarenko V. A., Laktionov B. I., Netis I. T. (1992). Intensive technologies of crops cultivation in the Kherson region, Ukraine, Kiev, 30.

12.Fisher R. A., Ronald A. Statistical methods for research workers. New Delhi: Cosmo Publications, 354.

\section{ОСОБЕННОСТИ ФОРМИРОВАНИЯ ЭЛЕМЕНТОВ СТРУКТУРЫ ПРОДУКТИВНОСТИ КУКУРУЗЫ ЗАВИСИМО ОТ НАЛИЧИЯ В МАТЕРИНСКОМ КОМПОНЕНТЕ ГЕНЕТИЧЕСКИХ МАРКЕРОВ}

\section{М. А. Макарчук}

Аннотация. Приведены особенности формирования основных элементов продуктивности коизогенных аналогов гибридов кукурузы при наличии в генотипах материнских компонентов генетических маркеров а2 и $A C R$ в различных генетических системах контролированного размножения. Доказано, что в условиях Правобережной Лесостепи и Южной Степи наличие в генотипе гибридов доминантных генетических маркеров ACR не приводит $к$ снижению урожайности, а в некоторых комбинациях способствует увеличению продуктивности.

Ключевые слова: гибрид, коизогенный аналог, генетический маркер, молдавский и парагвайский тип стерильности, закрепитель фертильности 


\title{
PECULIARITIES OF FORMING ELEMENTS OF THE MAIZE YIELD STRUCTURE DEPENDING ON THE EXISTENCE OF THE GENETIC MARKERS IN THEIR MATERNAL COMPONENTS M. A. Makarchuk
}

\begin{abstract}
The peculiarities of formation of the main productivity elements in the coisogenic analogues of maize hybrids with the existence of the genetic markers a2 and ACR in their maternal components in different genetic systems of the controlled breeding are described. It is proved that under the conditions of Right Bank Forest-Steppe and Southern Steppe, the existence of the dominant genetic markers ACR in the hybrids genotype does not lower their productivity, and even increases their yield.
\end{abstract}

Key words. hybrid, coisogenic analogue, genetic marker, $M$ - and P-type of sterility, fertility fixe 